\title{
Comparison of the Bromine and 4-Aminoantipyrine Methods for the Determination of Phenol Released from Utensils and Container-Packages in Contact with Food
}

\author{
(Received February 17, 1989)
}

\author{
Hajimu Ishiwata, Takiko Sugita and Kunitoshi Yoshinira \\ (National Institute of Hygienic Sciences : 1-18-1, Kamiyoga, Setagaya-ku, Tokyo, Japan)
}

\begin{abstract}
Two official analytical methods specified in the Japanese Food Sanitation Law for the determination of phenol released from food container-packages and utensils were compared. One method involves turbidimetry using bromine, and this is applied to formaldehyde resins such as phenol, urea and melamine resins. The other is colorimetry using 4-aminoantipyrine, a method applied to rubber products and cans coated with synthetic resin. In the former method, the percentage of positive visual detection of precipitate formation increased in a sigmoid manner with respect to the concentration of phenol. One hundred percent detection rate was attained at more than $25 \mathrm{ppm}$ phenol. Melamine, which might exist in the test solution prepared from melamine-formaldehyde resin, was also found to form a precipitate at only $10 \mathrm{ppm}$ upon addition of bromine. The latter method, colorimetry, showed a linear calibration curve, $y=0.0273 x+0.025, r=0.999$, where $y$ is optical density, $x$ is the concentration of phenol (ppm) and $r$ is the correlation coefficient, and was not affected by the coexistence of formaldehyde, urea or melamine up to $100 \mathrm{ppm}$. The colorimetry was confirmed to be better than the turbidimetry by applying both methods to migration solutions prepared from phenol resin products.
\end{abstract}

Key words: Food Sanitation Law of Japan; utensil and container-package; phenol; bromine method; 4-aminoantipyrine method; formaldehyde resin; phenol resin; melamine

The migration of phenol from utensils and container-packages in contact with food is regulated by the Food Sanitation Law of Japan. Two different official methods for different kinds of materials have been provided in the law for determination of the migration concentration of phenol in the test solution. One is turbidimetry using bromine, a method specified to be applied to plastic products made from resins based on formaldehyde (formaldehyde resins) such as phenol, urea and melamine resins. The other is colorimetry using 4-aminoantipyrine, a method specified to be applied to rubber products and cans coated with synthetic resin. The legal standard for phenol migration using the former method is that no precipitate be detected in the reaction mixture by visual observation. Although the turbidimetric detection limit for phenol is generally considered to be between 20 and $40 \mathrm{ppm},{ }^{1) 4)}$ there has been no report discussing in detail the relation between the detec- tion of precipitate and the concentration of phenol using this method. Phenol migration from rubber products and resin-coated cans is restricted to $5 \mathrm{ppm}$ when colorimetry is used.

In the present paper, we discuss the detection limit of phenol by turbidimetry, the correlation between results obtained by the two official methods, and the effect of coexisting substances in the test solution on the determination of phenol by turbidimetry and colorimetry.

\section{Materials and Methods}

\section{Samples*1}

Three types of tableware made of phenol resin, a bowl, and 2 kinds of boxes, were pur-

${ }^{* 1}$ The tableware used in the present experiments was coated with polyurethane or natural resin, and the phenol resin contained 55\% powdered wood. Thus they were not "phenol resin" according to the specification in the Food Sanitation Law of Japan. ${ }^{2)}$ 
chased from a department store in Tokyo. They were coated with natural resin (bowl) or polyurethane ( 2 boxes).

2. Apparatus

A Shimadzı UV-240 spectrophotometer (Shimadzu Corporation, Kyoto) was used.

\section{Reagents and test solution}

All reagents used were of special grade.

1) 4-Aminoantipyrine solution: $0.136 \mathrm{~g}$ of 4 aminoantipyrine was dissolved in water and made up to $100 \mathrm{ml}$.

2) Borate buffer solution: $70 \mathrm{ml}$ of $1 \mathrm{M}$ sodium hydroxide solution and $100 \mathrm{ml}$ of $1 \mathrm{M}$ boric acid solution were mixed.

3) Potassium ferricyanide solution: $0.86 \mathrm{~g}$ of potassium ferricyanide was dissolved in water. After the addition of $0.18 \mathrm{ml}$ of aqueous ammonia, the mixture was made up to $100 \mathrm{ml}$ with water.

4) Bromine-saturated water: $100 \mathrm{ml}$ of water was added to $3 \mathrm{ml}$ of bromine. The upper phase of the mixture was used after shaking well.

5) Acetylacetone solution: $150 \mathrm{~g}$ of ammonium acetate was dissolved in water, and $3 \mathrm{ml}$ of acetic acid and $2 \mathrm{ml}$ of acetylacetone were added. The mixture was made up to $1,000 \mathrm{ml}$ with water.

6) Phenol solution: $1.000 \mathrm{~g}$ of phenol was dissolved in water and made up to $100 \mathrm{ml}$. The solution was diluted to a definite concentration with water.

7) Formaldehyde solution: $2.655 \mathrm{~g}$ of formalin was dissolved in water and made up to $100 \mathrm{ml}$. The solution was diluted to a definite concentration with water.

8) Urea solution: $1.000 \mathrm{~g}$ of urea was dissolved in water and made up to $100 \mathrm{ml}$. The solution was diluted to a definite concentration with water.

9) Melamine solution: $100 \mathrm{mg}$ of melamine was dissolved in water and made up to $100 \mathrm{ml}$. The solution was diluted to a definite concentration with water.

4. Preparation of specimens and migration of phenol

The phenol resin products were cut to suitable size specimens (approximately $4 \mathrm{~cm} \times 10 \mathrm{~cm}$ ) with an electric saw, the coating resin was removed with sandpaper, and the specimens were rinsed with water. A specimen was put in water which had been heated to the appropriate temperature. The amount of water was equivalent to $2 \mathrm{ml}$ per $1 \mathrm{~cm}^{2}$ of surface area of the specimen. The beaker was covered with a watch glass and kept at $60^{\circ} \mathrm{C}$ or $95^{\circ} \mathrm{C}$ for $30 \mathrm{~min}$. The specimen was removed, and the solution was used as the test solution for the detection and determination of phenol.

\section{Detection and determination of phenol}

1) Turbidimetry

The method specified for formaldehyde resin ${ }^{5}$ was used, i. e., $0.25 \mathrm{ml}$ of bromine-saturated water was added to $5 \mathrm{ml}$ of the test solution. The mixture was left at room temperature for 1 hr. Visual observation of precipitate formation was performed by 10 to 12 volunteers working at the institute. The results of these observations were reported using the following point system: detection of precipitate (1 point); no detection of precipitate ( 0 point); judgement of the presence of a precipitate was difficult ( 0.5 point). The points were added, and total points were divided by the number of volunteers. Results are shown as percent detection.

2) Colorimetry

The method specified for rubber products ${ }^{6)}$ and coated cans ${ }^{7)}$ was used with minor changes, i. e., $0.6 \mathrm{ml}$ of borate buffer solution, $0.5 \mathrm{ml}$ of 4 -aminoantipyrine solution and $0.5 \mathrm{ml}$ of potassium ferricyanide solution were added to $4 \mathrm{ml}$ of the test solution, then made up to $20 \mathrm{ml}$ with water. The mixture was left at room temperature for $10 \mathrm{~min}$, then the optical density was measured at $505 \mathrm{~nm}$. The reaction volume used was $1 / 5$ of that prescribed in the official method, and optical density was measured at the $\lambda_{\max }$ of the reaction solution.

\section{Determination of formaldehyde}

An acetylacetone method $^{8)}$ was used, i. e., $5 \mathrm{ml}$ of the acetylacetone solution was added to $5 \mathrm{ml}$ of the test solution. The mixture was heated in a boiling water bath for $10 \mathrm{~min}$. After cooling, the optical density was measured at $415 \mathrm{~nm}$. Steam distillation of the test solution was omitted.

All experiments were carried out in duplicate, and the results are given as the mean value. Room temperature was $23 \pm 2^{\circ} \mathrm{C}$ throughout the experimental period. 
Table 1. Individual Judgments of Visual Detection of Phenol by Turbidimetry

\begin{tabular}{|c|c|c|c|c|c|c|c|c|c|c|c|c|c|c|c|}
\hline \multirow{2}{*}{ Phenol (ppm) } & \multicolumn{12}{|c|}{ Volunteer } & \multicolumn{3}{|c|}{ Detection } \\
\hline & $\mathrm{A}$ & $\mathrm{B}$ & $\mathrm{C}$ & $\mathrm{D}$ & $\mathrm{E}$ & $\mathrm{F}$ & G & $\mathrm{H}$ & I & $\mathrm{J}$ & $\mathrm{K}$ & $\mathrm{L}$ & Point & $\%$ & (Mean, \%) \\
\hline 0 & $\begin{array}{l}- \\
-\end{array}$ & $\begin{array}{l}- \\
-\end{array}$ & $\begin{array}{l}- \\
-\end{array}$ & - & $\begin{array}{l}- \\
-\end{array}$ & $\begin{array}{l}- \\
-\end{array}$ & $\begin{array}{l}- \\
-\end{array}$ & $\begin{array}{l}- \\
-\end{array}$ & + & - & - & $\begin{array}{l}- \\
-\end{array}$ & $\begin{array}{l}1.0 \\
0\end{array}$ & $\begin{array}{l}8 \\
0\end{array}$ & 4 \\
\hline 5 & $\overline{-}$ & $\begin{array}{l}- \\
-\end{array}$ & $\overline{-}$ & - & $\overline{-}$ & $\overline{ \pm}$ & - & $\overline{-}$ & $\overline{ \pm}$ & $\overline{-}$ & - & $\overline{-}$ & $\begin{array}{l}0 \\
1.0\end{array}$ & $\begin{array}{l}0 \\
8\end{array}$ & 4 \\
\hline 10 & $\begin{array}{l}- \\
-\end{array}$ & \pm & \pm & $\overline{-}$ & $\begin{array}{l}- \\
-\end{array}$ & $\begin{array}{l}- \\
-\end{array}$ & $\begin{array}{l}- \\
-\end{array}$ & $\begin{array}{l}- \\
-\end{array}$ & \pm & - & $\overline{-}$ & $\begin{array}{l}+ \\
\pm\end{array}$ & $\begin{array}{l}2.5 \\
1.0\end{array}$ & $\begin{array}{r}21 \\
8\end{array}$ & 15 \\
\hline 15 & $\begin{array}{l}- \\
-\end{array}$ & $\overline{-}$ & $\overline{+}$ & $\overline{ \pm}$ & $\begin{array}{l}- \\
-\end{array}$ & \pm & \pm & \pm & $\overline{-}$ & 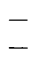 & \pm & $\begin{array}{l} \pm \\
\pm\end{array}$ & $\begin{array}{l}3.0 \\
2.5\end{array}$ & $\begin{array}{l}25 \\
21\end{array}$ & 23 \\
\hline 16 & $\begin{array}{l}- \\
-\end{array}$ & - & $\begin{array}{l}+ \\
\pm\end{array}$ & $\begin{array}{l}- \\
-\end{array}$ & - & \pm & $\begin{array}{l}- \\
-\end{array}$ & - & \pm & \pm & - & $\begin{array}{l}+ \\
+\end{array}$ & $\begin{array}{l}3.5 \\
3.0\end{array}$ & $\begin{array}{l}29 \\
25\end{array}$ & 27 \\
\hline 17 & $\begin{array}{l}- \\
-\end{array}$ & - & $\overline{ \pm}$ & \pm & - & \pm & $\frac{ \pm}{ \pm}$ & $\begin{array}{l}+ \\
+\end{array}$ & $\frac{ \pm}{+}$ & $\overline{-}$ & \pm & $\begin{array}{l}+ \\
+\end{array}$ & $\begin{array}{l}5.0 \\
5.0\end{array}$ & $\begin{array}{l}42 \\
42\end{array}$ & 42 \\
\hline 18 & \pm & $\overline{ \pm}$ & $\begin{array}{l}+ \\
+\end{array}$ & $\overline{ \pm}$ & $\begin{array}{l}- \\
-\end{array}$ & $\begin{array}{l}+ \\
+\end{array}$ & $\begin{array}{l}- \\
-\end{array}$ & $\frac{ \pm}{t}$ & \pm & \pm & $\begin{array}{l}+ \\
+\end{array}$ & $\begin{array}{l}+ \\
+\end{array}$ & $\begin{array}{l}6.0 \\
7.0\end{array}$ & $\begin{array}{l}50 \\
58\end{array}$ & 54 \\
\hline 19 & $\begin{array}{l}+ \\
+\end{array}$ & $\begin{array}{l}+ \\
+\end{array}$ & $\begin{array}{l}+ \\
+\end{array}$ & $\begin{array}{l}+ \\
+\end{array}$ & $\frac{ \pm}{ \pm}$ & $\begin{array}{l}+ \\
+\end{array}$ & $\begin{array}{l}+ \\
+\end{array}$ & $\begin{array}{l}+ \\
+\end{array}$ & $\begin{array}{l}+ \\
+\end{array}$ & $\begin{array}{l}+ \\
+\end{array}$ & $\begin{array}{l}+ \\
+\end{array}$ & $\begin{array}{l}+ \\
+\end{array}$ & $\begin{array}{l}11.5 \\
11.5\end{array}$ & $\begin{array}{l}96 \\
96\end{array}$ & 96 \\
\hline 20 & $\begin{array}{l}+ \\
+\end{array}$ & $\begin{array}{l}+ \\
+\end{array}$ & $\begin{array}{l}+ \\
+\end{array}$ & $\begin{array}{l}+ \\
+\end{array}$ & $\frac{ \pm}{ \pm}$ & $\begin{array}{l}+ \\
+\end{array}$ & $\begin{array}{l}+ \\
+\end{array}$ & $\begin{array}{l}+ \\
+\end{array}$ & $\begin{array}{l}+ \\
+\end{array}$ & $\begin{array}{l}+ \\
+\end{array}$ & $\begin{array}{l}+ \\
+\end{array}$ & $\begin{array}{l}+ \\
+\end{array}$ & $\begin{array}{l}11.5 \\
11.5\end{array}$ & $\begin{array}{l}96 \\
96\end{array}$ & 96 \\
\hline 25 & + & $\begin{array}{l}+ \\
+\end{array}$ & $\begin{array}{l}+ \\
+\end{array}$ & $\begin{array}{l}+ \\
+\end{array}$ & $\begin{array}{l}+ \\
+\end{array}$ & $\begin{array}{l}+ \\
+\end{array}$ & $\begin{array}{l}+ \\
+\end{array}$ & $\begin{array}{l}+ \\
+\end{array}$ & + & $\begin{array}{l}+ \\
+\end{array}$ & + & $\begin{array}{l}+ \\
+\end{array}$ & $\begin{array}{l}12.0 \\
12.0\end{array}$ & $\begin{array}{l}100 \\
100\end{array}$ & 100 \\
\hline 30 & $\begin{array}{l}+ \\
+\end{array}$ & $\begin{array}{l}+ \\
+\end{array}$ & $\begin{array}{l}+ \\
+\end{array}$ & + & $\begin{array}{l}+ \\
+\end{array}$ & $\begin{array}{l}+ \\
+\end{array}$ & $\begin{array}{l}+ \\
+\end{array}$ & $\begin{array}{l}+ \\
+\end{array}$ & $\begin{array}{l}+ \\
+\end{array}$ & $\begin{array}{l}+ \\
+\end{array}$ & $\begin{array}{l}+ \\
+\end{array}$ & $\begin{array}{l}+ \\
+\end{array}$ & $\begin{array}{l}12.0 \\
12.0\end{array}$ & $\begin{array}{l}100 \\
100\end{array}$ & 100 \\
\hline
\end{tabular}

+ : detection (1 point); \pm : difficult to judge ( 0.5 point); -: non-detection ( 0 point)

The mixture of $5 \mathrm{ml}$ of phenol solution and $0.25 \mathrm{ml}$ of bromine-saturated water was left at room temperature $\left(23^{\circ} \mathrm{C}\right)$ for $1 \mathrm{hr}$. Observation of the precipitate formation was performed by 12 volunteers. Detection percentage is given as total points/number of volunteers $\times 100$.

The experiments were carried out in duplicate.

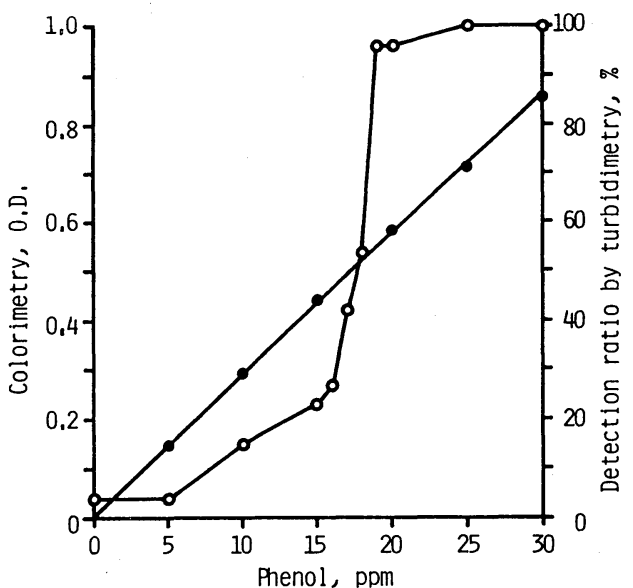

Fig. 1. Comparison of phenol detection by turbidimetry using bromine and by colorimetry using 4-aminoantipyrine $\mathrm{O}-\mathrm{O}$ : turbidimetry

- colorimetry

Observation of turbidimetric precipitate formation was performed by 12 volunteers.

\section{Results and Discussion}

1. Relation between results of turbidimetric and colorimetric determinations of phenol

In the present colorimetry experiments, $1 \mathrm{M}$ boric acid solution was used, and optical density was measured at $\lambda_{\max }, 505 \mathrm{~nm}$, instead of $3 M$ boric acid solution and $510 \mathrm{~nm}$, respectively. The $\mathrm{pH}$ of the mixture of $1 M$ sodium hydroxide solution and $1 M$ boric acid solution $(7: 10, \mathrm{v} / \mathrm{v})$ was 10.0. A linear calibration curve was obtained up to $30 \mathrm{ppm}$ phenol by colorimetry. The curve was described by the formula $y=0.0273 x$ $+0.025, r=0.999$, where $y$ is optical density, $x$ is concentration of phenol (ppm) and $r$ is the correlation coefficient.

On the other hand, the percent detection of precipitate by visual observation when turbidimetry was used yielded a sigmoid curve with respect to the concentration of phenol. The individual results of the observation of the reaction mixtures by volunteers are shown in Table 
Table 2. Precipitate Formation with Phenol and Other Monomers by the Addition of Bromine

\begin{tabular}{|c|c|c|c|c|c|c|c|c|c|c|c|}
\hline \multirow[b]{2}{*}{ Concentration (ppm) } & \multirow[t]{2}{*}{ Water } & \multirow{2}{*}{$\frac{\text { Phenol }}{20}$} & \multicolumn{3}{|c|}{ Formaldehyde } & \multicolumn{3}{|c|}{ Urea } & \multicolumn{3}{|c|}{ Melamine } \\
\hline & & & 1 & 10 & 100 & 1 & 10 & 100 & 1 & 10 & 100 \\
\hline Detection of precipitate (\%) & 5.0 & 100.0 & 0 & 0 & 2.5 & 0 & 0 & 2.5 & 2.5 & 100.0 & 97.5 \\
\hline
\end{tabular}

To $5 \mathrm{ml}$ of each solution, $0.25 \mathrm{ml}$ of bromine-saturated water was added.

Observation of the precipitate formation was performed by 10 volunteers.

Table 3. Inhibition of Precipitate Formation by Coexisting Substances in Turbidimetry

\begin{tabular}{|c|c|c|c|c|c|c|c|c|}
\hline \multirow[b]{2}{*}{ Concentration (ppm) } & \multirow[t]{2}{*}{ Water } & \multirow{2}{*}{$\frac{\text { Phenol }}{20}$} & \multicolumn{3}{|c|}{ Formaldehyde } & \multicolumn{3}{|c|}{ Urea } \\
\hline & & & 1 & 10 & 100 & 1 & 10 & 100 \\
\hline Detection of precipitate (\%) & 5.0 & 100.0 & 95.0 & 92.5 & 82.5 & 92.5 & 92.5 & 90.0 \\
\hline
\end{tabular}

Formaldehyde and urea solutions contained 20 ppm phenol.

Observation of the precipitate formation was performed by 10 volunteers.

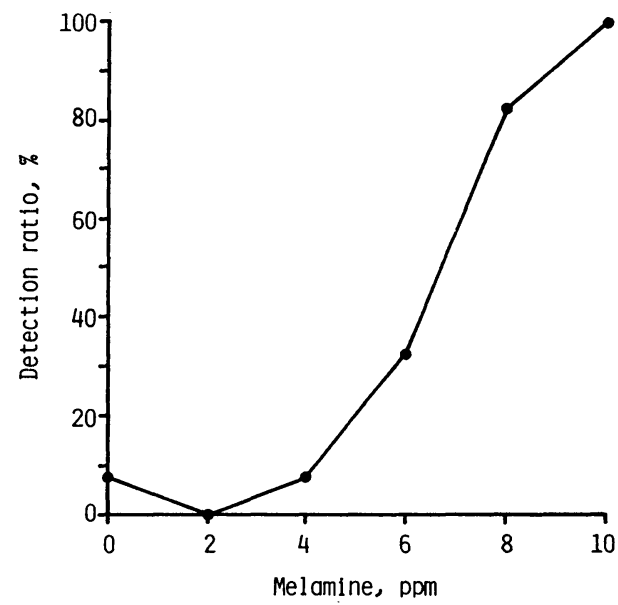

Fig. 2. Responsiveness of melamine to turbidimetry for the detection of phenol

To $5 \mathrm{ml}$ of melamine solution, $0.25 \mathrm{ml}$ of bromine-saturated water was added. Observation of the precipitate formation was performed by 10 volunteers.

1 , and the correlation between the detection ratio and concentration of phenol is shown in Fig. 1 together with a calibration curve obtained by colorimetry. One hundred percent detection was observed when the concentration was greater than $25 \mathrm{ppm}$ phenol. But $4 \%$ detection was observed even with the blank, i.e., $0 \mathrm{ppm}$ phenol. The percent detection of $5 \mathrm{ppm}$ phenol, the legal limit for migration from rubber products and coated cans, was $5 \%$. This percentage is approximately the same as with the blank. The colorimetric optical density of $5 \mathrm{ppm}$ phenol was 0.150 and was sufficient for determination.

Although there has been no previous study on the detection limit of turbidimetry, it has been suggested to be $20 \mathrm{ppm},{ }^{1)} 30 \mathrm{ppm},{ }^{2), 3)}$ or $40 \mathrm{ppm}$ 4) If the concentration corresponding to $100 \%$ detection is assumed to be the limit, it was 25 ppm in the present experiment. The characteristic problems in the turbidimetry, especially in visual detection of the precipitate, were that a) the calibration curve turned out to be sigmoid in shape, b) even water containing no phenol resulted some positive detection, c) by visual observation it is not possible to obtain zero detection with the blank solution, and d) what percent detection should be considered as a positive result? These problems are almost the same as those with visual detection of formaldehyde specified in the Food Sanitation Law of Japan ${ }^{5}$ as previously reported. ${ }^{9)}$

2. Effect of coexisting substances in the test solution on turbidimetry

Determination of phenol is specified for test solutions prepared from formaldehyde resins such as phenol, urea and melamine resins. Test solutions therefore may contain not only phenol but also formaldehyde, urea and melamine. These substances may inhibit precipitate formation by consuming bromine or interfere the detection of the precipitate formed from phenol by forming precipitates of their own by reacting with bromine.

The effect of these substances on turbidime- 
Table 4. Effect of Coexisting Substances in Colorimetry

\begin{tabular}{|c|c|c|c|c|c|c|c|c|c|c|}
\hline \multirow[b]{2}{*}{ Concentration (ppm) } & \multirow{2}{*}{$\frac{\text { Phenol }}{20}$} & \multicolumn{3}{|c|}{ Formaldehyde } & \multicolumn{3}{|c|}{ Urea } & \multicolumn{3}{|c|}{ Melamine } \\
\hline & & 1 & 10 & 100 & 1 & 10 & 100 & 1 & 10 & 100 \\
\hline Optical density & 0.568 & 0.567 & 0.540 & 0.570 & 0.570 & 0.575 & 0.580 & 0.542 & 0.563 & 0.569 \\
\hline $\begin{array}{l}\text { Relative } \\
\text { optical density (\%) }\end{array}$ & 100.0 & 99.8 & 95.0 & 100.4 & 100.0 & 101.2 & 102.1 & 95.4 & 99.1 & 100.2 \\
\hline
\end{tabular}

Formaldehyde, urea and melamine solutions contained $20 \mathrm{ppm}$ phenol.

Relative optical density is shown as a percentage of the optical density of a 20 ppm phenol solution.

Table 5. Application of the Two Official Analytical Methods for Phenol Determination to Migration Solutions Prepared from Test Specimens Composed of Phenol Resin

\begin{tabular}{|c|c|c|c|c|c|c|c|c|}
\hline \multirow{2}{*}{$\frac{\text { Test solution }}{\text { Migration temperature }\left({ }^{\circ} \mathrm{C}\right)}$} & \multirow[t]{2}{*}{ Water } & \multirow[t]{2}{*}{ Phenol } & \multicolumn{2}{|c|}{ Bowl } & \multicolumn{2}{|c|}{ Lunch Box A } & \multicolumn{2}{|c|}{ Lunch Box B } \\
\hline & & & 60 & 95 & 60 & 95 & 60 & 95 \\
\hline \multicolumn{9}{|l|}{ Detection of phenol } \\
\hline Colorimetry (ppm) & 0.0 & 20.0 & 2.7 & 10.0 & 2.0 & 19.4 & 2.3 & 11.3 \\
\hline Turbidimetry $(\%)^{*}$ & 5.0 & 100.0 & 27.5 & 32.5 & 5.0 & 47.5 & 10.0 & 22.5 \\
\hline Formaldehyde (ppm) & - & - & 0.4 & 1.5 & 0.4 & 3.9 & 0.4 & 2.2 \\
\hline
\end{tabular}

Preparation of test solution: specimens were kept in water at $60^{\circ} \mathrm{C}$ or $95^{\circ} \mathrm{C}$ for $30 \mathrm{~min}$. Observation of the precipitate formation was performed by 10 volunteers. Steam distillation was omitted from the determination of formaldehyde.

* See the footnote to Table 1.

try is shown in Tables 2 and 3 . It was found that melamine formed a precipitate upon addition of bromine. The percent detection of the precipitate was $100 \%$ in $10 \mathrm{ppm}$ melamine solution (Table 2), and the visual detection curve of the precipitate from melamine is shown in Fig. 2. The responsiveness of melamine to the method was two to three times higher than that of phenol, and the percent detection of a precipitate by visual observation also yielded a sigmoid curve in relation to the concentration of melamine. Although migration of melamine into water is very low ${ }^{10,11)}$, there are no restrictions on the migration of melamine from utensils and container-packages in contact with food. Turbidimetric assessments of phenol migration may be erroneous when the test solution contains melamine. No precipitate formation was observed in urea and formaldehyde solutions by this method with concentrations up to $100 \mathrm{ppm}$. Migration of formaldehyde is restricted to less than $4 \mathrm{ppm}$.

No inhibitory effect on precipitate formation was observed upon addition of urea or formaldehyde to the $20 \mathrm{ppm}$ phenol solution. The per- cent detection of precipitate was more than $80 \%$ in mixtures of $20 \mathrm{ppm}$ phenol and up to 100 ppm of urea or formaldehyde (Table 3 ). The percent detection of $20 \mathrm{ppm}$ phenol as a positive control was $100 \%$ in this experiment.

\section{Effect of coexisting substances in the test solu-} tion on colorimetry

The effect of formaldehyde, urea and melamine on the color development of phenol upon addition of 4-aminoantipyrine was examined for the same purpose as described above. Colorimetry was applied to $20 \mathrm{ppm}$ phenol solutions containing 1,10 and $100 \mathrm{ppm}$ of these coexisting substances. When the optical density of $20 \mathrm{ppm}$ phenol was taken as $100 \%$, the optical density of mixtures with coexistng substances was between 95.0 and 102.1\% (Table 4). No spectral differences were observed between the colored solution from phenol and those from phenol in the presence of these coexisting substances.

\section{Application of both methods to migration solu- tions prepared from phenol resin}

Both turbidimetry and colorimetry were applied to migration solutions prepared from spec- 
imens obtained from phenol resin products*1. The concentration of phenol in the test solution determined by colorimetry was approximately 2 $\mathrm{ppm}$ when the migration test was carried out at $60^{\circ} \mathrm{C}$, and 10 to $20 \mathrm{ppm}$ at $95^{\circ} \mathrm{C}$. The percent detection of precipitate by turbidimetry was between 5.0 and $27.5 \%$ in the test solution treated at $60^{\circ} \mathrm{C}$ and between 22.5 and $47.5 \%$ at $95^{\circ} \mathrm{C}$ (Table 5). In this case the percent detection of phenol in the blank and in $20 \mathrm{ppm}$ phenol solution were 5 and $100 \%$, respectively. The detection percentage of phenol in the test solutions determined by turbidimetry was not well related to the concentration determined by colorimetry. The highest concentration of phenol determined by colorimetry was $19.4 \mathrm{ppm}$ and the detection percent of precipitate in the same test solution was $47.5 \%$. Although the specimens were not the phenol resin specified in the Food Sanitation Law of Japan, formaldehyde was determined in the test solution, because phenol resin is produced from phenol and formaldehyde, and the migration of formaldehyde is restricted to $4 \mathrm{ppm}$. The migration concentrations of formaldehyde from the specimens were $0.4 \mathrm{ppm}$ in the former and 1.5 to $3.9 \mathrm{ppm}$ in the latter solution.

\section{Conclusion}

Two official methods for the determination of phenol released from food container-packages and utensils were compared.

1) Colorimetry using 4-aminoantipyrine applied to rubber products and cans coated with synthetic resins yielded a linear calibration curve up to $30 \mathrm{ppm}$ phenol, and was not affected by coexisting formaldehyde, urea or melamine up to $100 \mathrm{ppm}$.

2) Percent detection of precipitate by turbidimetry using bromine applied to formaldehyde resins yielded a sigmoid curve with respect to the concentration of phenol. One hundred percent detection was observed at more than 25 ppm phenol, but sometimes $100 \%$ detection rate was observed at $20 \mathrm{ppm}$ phenol. Five percent detection was observed even in the blank.

3) It was found that $10 \mathrm{ppm}$ of melamine formed a precipitate upon addition of bromine. This finding demonstrates that turbidimetry cannot be applied to detection of phenol in test solutions prepared from melamine resin products. Urea and formaldehyde up to $100 \mathrm{ppm}$ did not affect turbidimetry.

4) Both methods were applied to migration solutions prepared from specimens made of phenol resin. The detection percentage of phenol by turbidimetry did not correlate well to the concentration determined by colorimetry.

5) These results clearly demonstrate that colorimetry using 4-aminoantipyrine is more suitable than turbidimetry using bromine for detection and determination of phenol released from formaldehyde resin products.

\section{References}

1) Kikuchi, H., Ushizawa, I.: Ann. Rep. Miyagi Pref. Inst. Public Health Environm. 4, 152 153 (1986).

2) Food Chemistry Division, Ministry of Health and Welfare "Plastics for Food" p. 50 52 (1988) Japan Food Hygiene Association, Tokyo.

3) Baba, T.: J. Urban Living Health Assoc. 25, 236 $\sim 249$ (1981).

4) Mizutani, Y.: ibid. 16-1, 1 7 (1972)

5) Ministry of Health and Welfare "Notice No. 20", Kanpo p. 32, February 16 (1982).

6) Ministry of Health and Welfare "Notice No. 85", Kanpo p. 7 8, April 1 (1986).

7) Ministry of Health and Welfare "Notice No. 20", Kanpo p. 34, February 16 (1982).

8) Sugita, T., Ishiwata, H., Yoshihira, K.: J. Food Hyg. Soc. Japan 29, 273 279 (1988).

9) Inoue, T., Ishiwata, H., Yoshihira, K.: Bull. Natl. Inst. Hyg. Sci. 105, 101 103 (1987).

10) Ishiwata, H., Inoue, T., Tanimura, A.: Food Addit. Contam. 3, 63 70 (1986).

11) Sato, Y., Sato, K., Nakajima, S., Yoshida, R., Shiba, H., Fujii, T.: Ann. Rep. Tokyo Metr. Res. Lab. 24, 285 289 (1972). 